University of Rhode Island

DigitalCommons@URI

The Rhode Island Current Conditions Index

Economics

$12-2007$

\title{
Rhode Island Current Conditions Index - December 2007
}

Leonard Lardaro

University of Rhode Island, lardaro@uri.edu

Follow this and additional works at: https://digitalcommons.uri.edu/ricci

Part of the Econometrics Commons

Terms of Use

All rights reserved under copyright.

\section{Recommended Citation}

Lardaro, Leonard, "Rhode Island Current Conditions Index - December 2007" (2007). The Rhode Island Current Conditions Index. Paper 61.

https://digitalcommons.uri.edu/ricci/61

This Article is brought to you for free and open access by the Economics at DigitalCommons@URI. It has been accepted for inclusion in The Rhode Island Current Conditions Index by an authorized administrator of DigitalCommons@URI.For more information, please contact digitalcommons-group@uri.edu. 


\section{BURRENT BONDITIONS

Rhode Island ended 2007 on a bittersweet note. While the Current Conditions Index improved from its recent low values, it remained in the declining range, nonetheless.

The Current Conditions Index for December was 42 - in the contracting range for the fifth consecutive month (after posting a neutral value in July). Recession performance continues. And, while recessions have stages, Rhode Island may well have begun the transition from the early to middle recession stages as 2007 ended. This might not be apparent in the data available as of the time of this report, but labor market data will soon be "rebenchmarked." My econometric analysis of labor market data points to the strong likelihood of a downward revision to payroll employment. As misery loves company, I have altered my assessment of the US economy. Based on the recent behavior of a number of national indicators, most notably the stunning drop in service sector activity, I now believe that the US is either in a recession that began in late December, or about to enter a recession period.

Rhode Island's economic weakness continued to be spread across most sectors in December. While two of the $\mathrm{CCl}^{\prime} \mathrm{s}$ leading indicators improved in December, consistent improvement in them is very unlikely. Single-Unit Permits, which measures new home construction, rose by 26.4 percent

\begin{tabular}{|l|r|}
\hline \multicolumn{2}{|c|}{ CCI Indicators - \% Change } \\
\hline Government Employment & -0.5 \\
\hline US Consumer Sentiment & -17.6 \\
\hline Single-Unit Permits & 26.4 Y \\
\hline Retail Sales & -11.0 \\
\hline Employment Services Jobs & -11.6 \\
\hline Priv. Serv-Prod Employment & 1.2 Y \\
\hline Total Manufacturing Hours & -3.9 \\
\hline Manufacturing Wage & 4.5 Y \\
\hline Labor Force & 0.1 Y \\
\hline Benefit Exhaustions & 24.9 \\
\hline New Claims & $-4.3 \mathbf{Y}$ \\
\hline Unemployment Rate & 7.8 \\
\hline \multicolumn{2}{|c|}{ Y $=$ Improved Value } \\
\hline
\end{tabular}

compared to last December. Large inventories of unsold homes will continue to hurt Permits in coming months. And New Claims, a measure of layoffs, also improved (it fell) for only the second time in the last year. Further improvement there is not something we will see very soon in a recession climate.

Labor market weakness continued. The Unemployment Rate failed to improve for the second consecutive month, rising to
5.5 percent. It is quite possible that its 2007 values might soon be revised higher. Our Labor Force barely grew in December $(+0.1 \%)$, as its decelerating growth continued.

Other than Permits and New Claims, the $\mathrm{CCl}$ 's other two leading indicators failed to improve again in December. Employment Service Jobs, which includes "temp" positions, fell again at a double-digit rate again in December $(-11.6 \%)$, its fifth consecutive monthly decline and a long way from its string of double-digit increases that extended from October 2006 through March of 2007. Total Manufacturing Hours, declined at a accelerating rate in December $(-3.9 \%)$, signaling intensifying weakness in that sector. Both employment and the workweek fell, which is consistent with a declining capacity utilization rate in manufacturing. One irony continued: despite the overall weakness in Rhode Island's economy and in Total Manufacturing Hours, the Manufacturing Wage grew at its fastest rate in years $(+4.5 \%)$, signaling ongoing skill shortages in manufacturing!

Other indicators continued to turn in disappointing performances. US Consumer Sentiment fell by 17.6 percent in December, while the end of a so-so holiday shopping season caused Retail Sales weakness to accelerate, as it declined at a double-digit rate $(-11 \%)$. Private Service-Producing Employment growth remained sluggish $(+1.2 \%)$, and Government Employment fell yet again, by 0.5 percent.

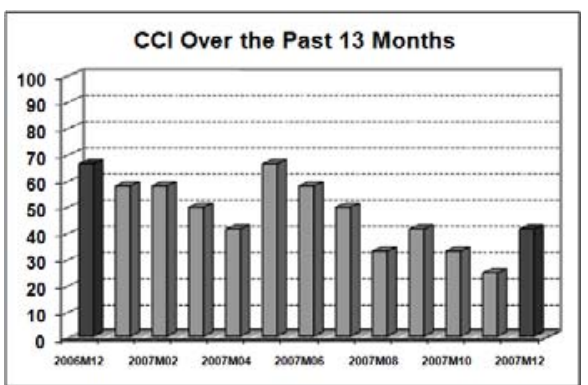

\section{THE BOTTOM LINE}

Based on the data available up to this point, 2007 was a bad year for Rhode Island's economy. Not only did it slip into recession during late summer, the annual average for the $\mathrm{CCl}$ was in the declining range (47). Rebenchmarked labor market data will soon be released. While there will likely be some changes to $\mathrm{CCl}$ values, expect the overall pattern to remain.

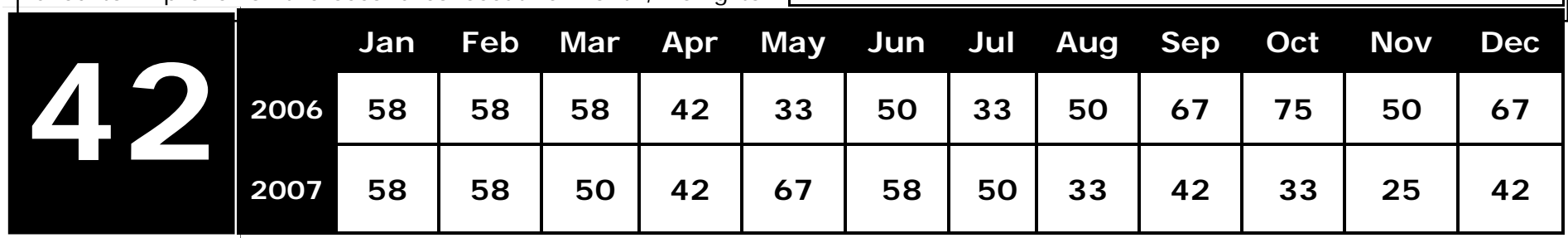

